DOI https://doi.org/10.30525/978-9934-588-37-2.1.22

\title{
ПІДГОТОВКА ДІТЕЙ 3 ІНТЕЛЕКТУАЛЬНИМИ ПОРУШЕННЯМИ ДО ОПАНУВАННЯ ГРАМОТИ
}

\author{
Кузьмінська Є. О., Піонтківська Г. С.
}

\section{ВСТУП}

Актуальність проблеми підготовки до опанування грамоти дітей 3 інтелектуальними порушеннями зумовлена концептуальними засадами та державними вимогами реформування освіти в Україні, спрямованими на підвищення загальномовної та мовленнєвої культури дітей, про що зазначається в «Базовому компоненті дошкільної освіти», «Концепції спеціальної мовної освіти», «Державному стандарті базової і повної середньої освіти», «Державному стандарті початкової загальної освіти для дітей 3 особливими освітніми потребами», «Державному стандарті спеціальної освіти дітей з особливими потребами» ${ }^{1}$.

Аналіз науково-педагогічної літератури з проблеми підготовки дітей до опанування грамоти в історичному аспекті свідчить про невичерпність актуальності цієї проблеми навіть на сучасному етапі, що відображено у напрацюваннях Є. Адамовича, В. Вахтерова, М. Вашуленка ${ }^{2}$, С. Дорошенка, М. Монтесорі, Ж. Піаже, С.Рєдозубова ${ }^{3}$, Н. Рождественського, Д. Тихомирова, К. Ушинського, Я. Чепіги, В. Флєрова та ін.

Проблема підготовки до опанування грамоти дітей розглядається у психолого-педагогічних дослідженнях зарубіжних і вітчизняних вчених y різних аспектах: фізіологічних i психологічних механізмах мовленнєвої діяльності (В. Дегліна, Д. Ельконін, Т. Єгоров, М. Жинкін, Л. Калмикова, Н. Красногорський, О. Леонтьєв, О. Лурія, Н. Лях, М. Львов, І. Павлов, Н. Рождественський, Т. Рамзаєва, С. Рєдозубов, Н. Свєтловська, М. Феофанов, Т. Чернігівська, Л. Щерба та ін.), теорії мовленнєвої діяльності (Л. Виготський, О. Леонтьєв та ін.), поетапного формування розумових дій (П. Гальперін), розвитку сприймання звукової структури слова (А. Богуш ${ }^{4}$, Г. Бєляков, М. Вашуленко,

\footnotetext{
${ }^{1}$ Базовий компонент дошкільної освіти / наук. кер. : А.М. Богуш. Київ, 2012. 26 с.

2 Вашуленко М.С. Навчання грамоти в першому класі чотирирічної початкової школи : посібник. Київ : Рад. шк., 1986. 166 с.

${ }^{3}$ Рєдозубов С.П. Обучение грамоте. Москва : Учпедгиз, 1952. 52 с.

${ }^{4}$ Богуш А.М. Витоки мовленнєвого розвитку дітей дошкільного віку: програма та методичні рекомендації. Київ : ІЗМН, 1997. 112 с.
} 
Н. Варенцова, І. Дьоміна, Л. Журова, К. Прищепа, Т. Ткаченко, Ф. Сохін, Н. Скрипченко та ін.), оволодінням процесом письма (А. Богуш, Н. Виноградова, І. Дьоміна, Д. Ельконін, О. Лурія 5 , I. Корякіна, С. Рєдозубов, В. Савельєва та ін.).

У сучасній науково-методичній літературі навчання грамоти визначається як процес формування у дітей початкових умінь читання $\mathrm{i}$ письма. Метою навчання грамоти $є$ формування й удосконалення умінь $\mathrm{i}$ навичок у дітей в усіх видах мовленнєвої діяльності - слуханні й розумінні, говорінні, читанні та письмі (А. Богуш, Г. Бєляков, М. Вашуленко, Н. Варенцова ${ }^{6}$, І. Дьоміна, Д. Ельконін, Л. Журова, К. Прищепа, Т. Ткаченко, С. Рєдозубов, Ф. Сохін, Н. Скрипченко та ін.).

У психологічній i методичній літературі (М. Генінг, Н. Дурова, Д. Ельконін, Л. Журова, Л. Ткачова, Г. Тумакова та ін.) обгрунтовано, що навчання грамоти потрібно починати з дошкільного віку, оскільки в 5-6 років утворюються умовно-рефлекторні функціональні зв'язки, які лежать в основі процесів читання та письма, що має важливе значення для початкового формування усного й писемного мовлення дітей.

Мовленнєва компетенція охоплює систему мовленнєвих умінь, необхідних дітям для спілкування у різних ситуаціях. Вона передбачає сформованість фонетичної, лексичної, граматичної, діалогічної та монологічної компетенцій (А. Богуш ${ }^{7}$, М. Пентелюк та ін.).

Психолого-педагогічні дослідження особливостей розвитку дітей 3 інтелектуальними порушеннями вітчизняних i зарубіжних науковців Г. Дульнєва, І. Дмитрієвої, І. Єременка, Л. Занкова, Р. Лалаєвої, О. Лурія С. Миронової, М. Певзнер, В. Петрової ${ }^{9}$ ， І. Романенко, В. Синьова, М. Супруна, О. Чеботарьової, Д. Шульженко та ін. свідчать, що мовлення відіграє провідну роль у психічному розвитку дітей цієї категорії. Зокрема, мисленнєві операції - аналіз, синтез, порівняння, узагальнення, абстрагування - розвиваються й удосконалюються у процесі оволодіння мовленням (Л. Виготський, Л. Вавіна ${ }^{10}$, М. Гнєзділов, Г. Дульнєв, I. Сременко, Л. Занков, Н. Кравець, О. Лурія, Р. Лалаєва， М. Певзнер,

5 Лурия А.Р. Высшие корковые функции человека и их нарушение при локальных поражениях мозга. Москва : Изд-во Московского ин-та, 1975. 374 с.

${ }^{6}$ Варенцова Н.С. Возрастные особенности усвоения грамоты детьми 5-ти лет : автореф. дис. ... канд. пед. наук. Москва, 1978. 24 с.

Богуш А.М. Витоки мовленнєвого розвитку дітей дошкільного віку: програма та методичні рекомендації. Київ : ІЗМН, 1997. 112 с.

8 Лурия А.Р. Высшие корковые функции человека и их нарушение при локальных поражениях мозга. Москва : Изд-во Московского ин-та, 1975. 374 с.

9 Петрова В.Г. Развитие речи учащихся вспомогательной школы. Москва : Педагогика, 1977. 200 с.

10 Вавіна Л.С. Методичні рекомендації з вивчення грамоти учнів I-II відділень допоміжної школи. Київ : РУМК спец. шкіл, 1990. 112 с. 
В. Петрова, Г. Піонтківська, С. Рубінштейн, В. Синьов ${ }^{11}$, Є. Соботович, Т. Ульянова, Ж. Шиф та ін.).

Зниження регулюючої функції, а також інші порушення мовлення у дітей 3 інтелектуальними порушеннями зумовлені насамперед недорозвиненням пізнавальної діяльності, порушенням фонематичних, фонетичних процесів, вадами будови артикуляційного апарату та іншими факторами (М. Гнєзділов, О. Лурія, В. Лубовський та ін.). Основними порушеннями у дітей цієї категорії є своєрідний загальний i мовленнєвий розвиток, який зумовлює виникнення значних труднощів у процесі оволодіння грамотою.

Характерною ознакою дітей 3 інтелектуальними порушеннями $\epsilon$ несформованість у них усіх етапів мовленнєвої діяльності, що значно ускладнює процес формування мовленнєвої компетенції. А несформованість всіх сторін мовленн - фонетичної, лексичної, граматичної призводить до специфіки оволодінням ними процесом читання та письма (М. Гнєзділов ${ }^{12}$, . Петрова, С. Рубінштейн, С. Соботович, Т. Ульянова та ін.).

Оскільки у цієї категорії дітей спостерігається недорозвинення як загальної, так і дрібної моторики, несформованість орієнтування у просторі, в т. ч. і на аркуші паперу, невміння переключатися з однієї діяльності на іншу (А. Аксьонова, Л. Вавіна, В. Воронкова, М. Гнєзділов, Н. Кравець, Р. Левіна, К. Островська, В. Петрова ${ }^{13}$, Г. Піонтківська, В. Синьов, Т. Ульянова, Д. Шульженко та ін.), то важливо ще в дошкільний період проводити ефективну підготовку дітей цієї категорії до опанування грамоти, яка передбачає оволодіння ними початковими елементарними навичками читання і письма.

Незважаючи на різні аспекти теоретичного й емпіричного вивчення особливостей підготовки до опанування грамоти дітей 3 інтелектуальними порушеннями старшого дошкільного та молодшого шкільного віку, методичне вирішення досліджуваної проблеми залишається недостатньо розробленим.

\section{1. Стан підготовки до опанування грамоти дітей}

\section{з інтелектуальними порушеннями}

Як зазначають Г.П. Бєляков, Д.Н. Богоявленський, Є.В. Гурьянов, Д.Б. Ельконін, Т.Г. Єгоров, М.С. Рождественський, Ф.О. Сохін та ін.,

${ }^{11}$ Синьов В.М. Корекційна психопедагогіка. Олігофренопедагогіка : підручник. Ч. 1. Загальні основи корекційної психопедагогіки (олігофренопедагогіка). Київ : Вид-во НПУ імені М.П. Драгоманова, 2007. 238 с.

12 Гнездилов М.Ф. Обучение грамоте во вспомогательной школе. Москва : Учпедгиз, 1989. 96 с.

13 Петрова В.Г. Развитие речи учащихся вспомогательной школы. Москва : Педагогика, 1977. 200 с. 
для оволодіння процесом навчання грамоти необхідно: розрізняти звуки у словах на слух; співвідносити почутий звук мовлення 3 потрібним знаком; навчитися сприймати не лише кожну букву, а й за асоціацією вимовляти відповідний їй звук; уявляти звуко-буквенну структуру слова та розуміти його граматичне та лексичне значення; злитно співвідносити всі букви у слові; розуміти розташування слова у реченні. Ці автори наголошують, що все це потребує від дітей розвинутого фонематичного слуху, володіння мовленнєво-руховим апаратом i зоровим сприйманням слова, вмінням встановлювати зв'язок між слуховими, зоровими та руховими образами в писемному мовленні.

Метою констатувального етапу дослідження було виявлення рівня підготовки до опанування грамоти дітей 3 інтелектуальними порушеннями старшого дошкільного та молодшого шкільного віку залежно від стану сформованості в них мовленнєвої компетенції 14 .

У дослідженні брала участь 131 дитина 3 інтелектуальними порушеннями старшого дошкільного та молодшого шкільного віку.

Аналіз «Програми розвитку дітей дошкільного віку з розумовою відсталістю» ${ }^{15}$ та «Програми загальноосвітнього навчального закладу для розумово відсталих учнів. Українська мова, Підготовчий, 1 класи» дозволив виділити основні компоненти підготовленості до опанування грамоти дітей 3 інтелектуальними порушеннями: мовленнєву компетенцію, сформованість початкових елементарних навичок читання й елементарних навичок письма.

Критерії мовленнєвої компетенції: правильна звуковимова, інтонаційна насиченість і виразність мовлення; достатній словниковий запас, розуміння семантики слів і вживання їх у правильному значенні; вживання слів у правильній граматичній формі, правильна граматична $i$ синтаксична будова мовлення; слухання, сприймання та розуміння зверненого мовлення; слухання і розуміння змісту простих і коротких текстів, уміння відповідати на поставлені запитання у межах знайомого мовленнєвого матеріалу, уміння брати активну участь у діалозі; складати речення, розповіді за сюжетними малюнками, переказувати знайомий текст і зміст переглянутого мультфільму.

Критерії сформованості початкової елементарної навички читання: розвиненість фонетико-фонематичного слуху, сприймання та розпізнавання мовленнєвих звуків; уміння правильно вимовляти звуки,

14 Кузьмінська Є.О. Підготовка розумово відсталих дітей до опанування грамоти : дис. ... канд. пед. наук. Київ, 2015. 197 с.

${ }^{15}$ Програма розвитку дітей дошкільного віку з розумовою відсталістю. Розвиток мовлення / І.М. Дуброва, В.П. Лощених, Л.П. Шмалько. Київ, 2013. 14 с. 
слухати та повторювати їх за експериментатором, вимовляти звукосполучення, прості за структурою слова, виконувати звуковий аналіз слова, сприймати та розуміти складову структуру слова, уміти визначати на слух кількість слів у реченні та графічно їх позначати.

Критерії сформованості початкової елементарної навички письма: дотримання правил гігієни письма, розвиток дрібної моторики рук, просторового орієнтування, дотримання правил штрихування, уміння виконувати завдання за інструкцію, роботу за зразком, використовуючи допомогу експериментатора.

Кожна дитина повинна була виконати декілька завдань, які за необхідності деталізувалися, уточнювалися та диференціювалися. Добір завдань здійснювалося з урахуванням їх продуктивно-творчого характеру відповідно до програмних вимог із розвитку мовлення й української мови в умовах диференційованого навчання.

Враховуючи вищесказане, для перевірки стану мовленнєвої компетенції було запропоновано виконати учням три блоки завдань.

Перший блок завдань був спрямований на вивчення активного та пасивного словникового запасу у дітей 3 інтелектуальними порушеннями 4-го року навчання спеціальних дошкільних навчальних закладів і підготовчих класів спеціальних загальноосвітніх шкіл. Дітям пропонувалося виконати такі завдання:

Завдання 1. Назвати предмет, зображений на малюнку.

Завдання 2. Які дії зображено?

Завдання 3. Показати названий малюнок.

Другий блок завдань спрямований на вивчення у дітей цієї категорії сформованості мовленнєвих узагальнень. Для цього їм пропонувалося виконати таке завдання:

Завдання. Підібрати узагальнюючі поняття до запропонованих слів.

У третьому блоці завдань у дітей з інтелектуальними порушеннями перевірялися сформованість граматичної будови мовлення, уміння використовувати діалог відповідно до ситуації спілкування і монологічне мовлення. Для цього діти повинні були виконати такі завдання:

Завдання 1. Розглянути малюнок і скласти речення.

Завдання 2. Скласти розповідь за серією малюнків.

Завдання 3. Уважно розглянути малюнок. Дати відповідь на запитання експериментатора.

Завдання 4. Поставити запитання до малюнку.

Завдання 5. Робота із віршем.

Завдання 6. Послухати та переказати оповідання.

Завдання 7. Робота з казкою.

Завдання 8. Перегляд мультфільму «Капітошка». 
Для виявлення стану сформованості початкової елементарної навички читання дітям у лабораторних умовах пропонувалося виконати декілька блоків завдань, так, перший блок завдань передбачав вивчення стану розвитку фонематичного слуху і слухового сприймання у дітей 3 інтелектуальними порушеннями старшого дошкільного та молодшого шкільного віку. До нього увійшли такі завдання:

Завдання 1. Закрити долонькою малюнок.

Завдання 2. Послухати та повторити склади.

Завдання 3. Послухати та повтори слова.

Другий блок завдань спрямований на визначення стану розвитку орієнтування у звуковій структурі слова. Дітям з інтелектуальними порушеннями було запропоновано виконати такі завдання:

Завдання 1. Знайти спільний голосний звук.

Завдання 2. Знайти спільний приголосний звук.

Завадння 3. Які голосні звуки ти чуєш у слові?

Завдання 4. Назвати перший звук у слові.

Завдання 5. Визначити останній звук у слові.

Завадння 6. Звуковий аналіз слова.

Третій блок завдань був спрямовний на виявлення у дітей цієї категорії вмінь орієнуватися у складовій будові слова; на слух визначати кількість слів у реченні та графічно їх позначати. Цей блок склали такі завдання:

Завдання 1. Поділити слова на склади.

Завдання 2. Визначити кількість слів у реченні.

Завдання 3. Зробити графічну схему речення.

Для виявлення стану сформованості початкової елементарної навички письма дітям було запропоновано виконати такі завдання:

Завдання 1. Заштрихувати предмети.

Завдання 2. Виконати завдання за зразком до кінця рядка.

Аналіз і узагальнення результатів, одержаних на констатувальному етапі дослідження, дозволили розподілити учнів на чотири якісні рівні залежно від стану підготовленості до опанування грамоти дітей 3 інтелектуальними порушеннями старшого дошкільного та молодшого шкільного віку (рис. 1$)^{16}$.

Як показали результати констатувального експерименту, до першого рівня не була віднесена жодна дитина, оскільки більшість завдань, які пропонувалися їм, були досить складними для їх виконання.

16 Кузьмінська Є. О. Підготовка розумово відсталих дітей до опанування грамоти : дис. ... канд. пед. наук. Київ, 2015. 197 с. 


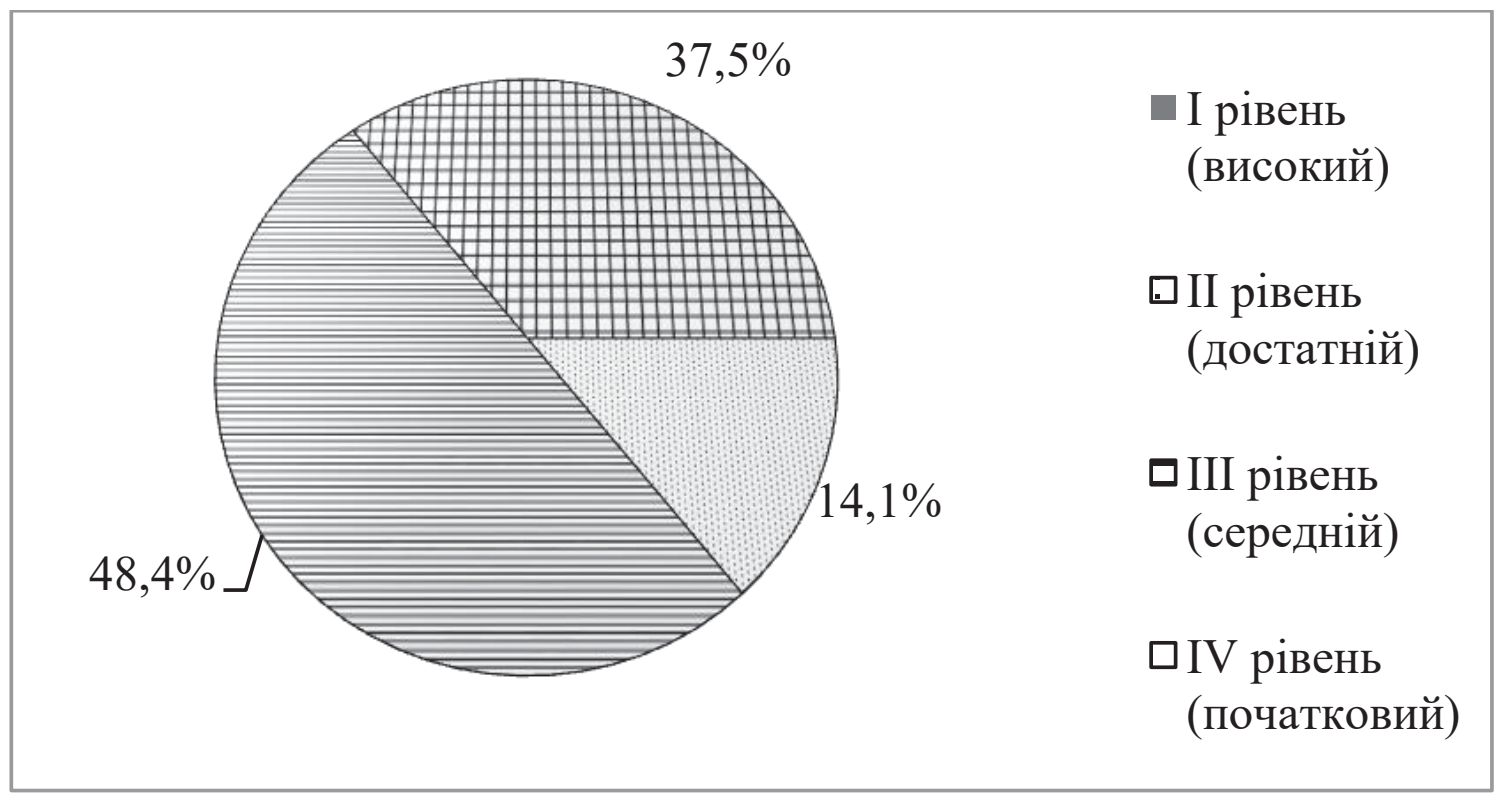

Рис. 1. Розподіл дітей з інтелектуальними порушеннями за рівнями підготовленості до опанування грамоти (у\%)

Особливий інтерес викликають діти, які показали достатні знання та вміння і увійшли до другого рівня - 14,1\% дітей. У них сформовані певні знання, необхідні для підготовки до навчання грамоти, зокрема вони мають уявлення про звукову та складову структуру слова, але при диференціації голосних i приголосних звуків на слух допускають незначні помилки. Розпізнають на слух слова, що починаються на заданий звук, самостійно складають моделі слів зі дидактичного матеріалу, але у них зустрічаються труднощі у визначенні та позначенні м'яких приголосних, виокремлюють речення 3 мовленнєвого потоку, визначають його межі лише за допомогою експериментатора, повторюють його, визначають кількість i послідовність слів у реченні, вміють викладати графічну будову речення, використовуючи допомогу дослідника. Діти за предметними та сюжетними малюнками складають речення з одного, двох слів, але не завжди узгоджують слова у реченні, за допомогою експериментатора переказують простий текст з опорою на запитання, ілюстрації, вміють 3 опорою на предметні та сюжетні малюнки будувати короткі зв'язні висловлювання, але потребують незначної допомоги. Вони невпевнено орієнтуються на площині аркуша паперу, часто зустрічається неохайність у виконанні завдання.

Одержані дані дозволяють констатувати, що у дітей, котрі виконали завдання на достатньому рівні, мовленнєві знання та вміння, необхідні для навчання грамоти, загалом сформовані, але практичні мовленнєві уміння неусвідомлені, механічні, відсутня мотивація та творчий підхід до виконання завдань. 
До середнього рівня було віднесено 48,4\% дітей, які мали часткові знання про звукову структуру слова, у них спостерігалися труднощі під час називання приголосних звуків. Вони частково розпізнавали слова на слух, що розпочиналися на заданий звук, і частково виконували звуковий аналіз слова, використовуючи моделі звуків. Діти з великими труднощами виділяли слова 3 мовленнєвого потоку та ділили їх на склади. Лише за допомогою експериментатора вони виокремлювали речення з мовленнєвого потоку, визначали його межі, повторювали його, розподіляли прості речення на слова, визначали їх кількість i послідовність; за предметними та сюжетними малюнками складали прості речення, не узгоджували слів у реченнях, не переказували текст, навіть використовуючи допомогу експериментатора, на поставлені запитання до тексту давали фрагментарні відповіді. Діти навіть під контролем учителя не завжди дотримувалися відповідних інтонацій під час діалогу (запитальної, окличної, розповідної), чітко не орієнтувалися у сюжетному малюнку, тому описували його одним-двома словами. Вони не орієнтувалися на площині аркушу паперу, за допомогою експериментатора розрізняли напрямки штрихування, дотримувалися їх лише за допомогою експериментатора, частково розуміли завдання, тому не виконували роботу за зразком.

Ці труднощі, на нашу думку, виникли внаслідок несформованості потрібних знань i вмінь дітей 3 інтелектуальними порушеннями старшого дошкільного та молодшого шкільного віку, а також недостатності загального та мовленнєвого розвитку, що суттєво позначилося на успішності виконання завдань. Навчальні можливості цих дітей досить низькі.

Під час проведення дослідження до початкового (IV) рівня було віднесено 37,5\% дітей. Вони не мали чітких знань про звукову структуру слова, не диференціювали голосних і приголосних звуків на слух, мали значні труднощі під час звукового аналізу слова, не викладали звукову модель слова, не мали чіткого уявлення про складову будову слова, не виділяли кількість слів у реченні та не викладали графічну схему речення. Активний і пасивний словник у цих дітей бідний, вони не розуміли змісту сюжетних малюнків, розуміли лише деякі запитання до сюжету малюнка, відповідали на них одним словом. Діти не сприймали навіть нескладні тексти (казку, вірш), не переказували їх за допомогою запитань, не використовували допомогу експериментатора. Вони зовсім не орієнтувалися на сторінці зошита, в межах рядка, самостійно не виконували штрихування предметів різними лініями в різних напрямках, не виконували завдань за зразком, оскільки не розуміли інструкцій експериментатора. Навчальні можливості цих представників дуже низькі. Діти потребували у процесі навчання постійного індивідуального підходу. 
Як показали результати констатувального етапу експерименту, у більшості дітей 3 інтелектуальними порушеннями старшого дошкільного та молодшого шкільного віку недостатньо сформований мовленнєвий досвід, необхідний для опанування ними грамоти.

Проведене дослідження дозволяе зробити висновок про необхідність розробки спеціальної корекційної роботи, спрямованої на підготовку до опанування грамоти дітей 3 інтелектуальними порушеннями старшого дошкільного та молодшого шкільного віку.

\section{2. Методика корекційної роботи з підготовки дітей} з інтелектуальними порушеннями до опанування грамоти

На основі аналізу дидактико-методичних принципів загальної та спеціальної методики навчання мови та 3 урахуванням особливостей пізнавальної діяльності дітей 3 інтелектуальними порушеннями розроблена методика корекційної роботи з їх підготовки до опанування грамоти.

При розробці методики корекційної роботи 3 підготовки до опанування грамоти дітей цієї категорії ми орієнтувалися на практичні напрацювання вивчення дітей, дані про їх мовленнєвий розвиток А. Богуш ${ }^{17}$, Л. Варзацької, М. Вашуленка, І. Дмитрієвої, С. Миронової та ін., а також виявлені у процесі констатувального етапу дослідження труднощі, яких зазнавали діти під час виконання завдань, адаптувавши їх відповідно до завдань дослідження.

Зміст розробленої експериментальної методики передбачав дотримання таких вимог:

- реалізації основних завдань підготовки до опанування грамоти у взаємозв'язку з цілеспрямованим розвитком у дітей з інтелектуальними порушеннями виявлених прогалин у мовленнєвій діяльності;

- спрямування корекційної роботи 3 удосконалення в дітей фонетико-фонематичної, зорової та просторової підготовленості до опанування грамоти;

- забезпечення активного мовленнєвого розвитку дітей у процесі збагачення словникового запасу, уміння практично складати речення, формування діалогічного та монологічного мовлення.

Методика корекційної роботи базувалася на врахуванні таких умов:

- введення завдань у навчальний процес для формування практичних випереджуючих знань із метою утворення зв'язків, які будуть базою для опанування грамоти;

${ }^{17}$ Богуш А.М. Витоки мовленнєвого розвитку дітей дошкільного віку: програма та методичні рекомендації. Київ : ІЗМН, 1997. 112 с. 
- використання під час вивчення кожної нової теми пропедевтичної роботи;

- систематичного застосування індивідуального підходу в навчальному процесі з метою розвитку пізнавальної діяльності дітей 3 інтелектуальними порушеннями;

- підбору доступних і цікавих завдань для розвитку емоційновольової сфери, підвищення активності, працездатності, мотивації дітей 3 інтелектуальними порушеннями;

- спрямованості корекційної роботи на удосконалення і розвиток фонетико-фонематичного слуху;

- формування просторового орієнтування i розвитку дрібної моторики для успішного навчання дітей умінню орієнтуватися на аркуші паперу;

- обов’язкового оцінювання дітей на кожному занятті;

- застосування на кожному занятті ігор та ігрових прийомів, базуючись на особливостях розвитку дітей 3 інтелектуальними порушеннями;

- застосування схем-опор для закріплення навчального матеріалу дітьми;

- використання спеціального педагогічного керівництва діяльністю дітей із розвитку мовлення шляхом застосування коментованого управління;

- практичного вивчення нової теми без використання теоретичних узагальнень у зв'язку із труднощами, які виникають у процесі оволодіння теоретичними поняттями та категоріями.

Методика дослідження проходила у два етапи - підготовчий та основний.

Метою підготовчого етапу був корегуючий розвиток мовленнєвої компетенції дітей 3 інтелектуальними порушеннями старшого дошкільного і молодшого шкільного віку.

Як встановлено на констатувальному етапі дослідження, у дітей цієї категорії спостерігається недостатня сформованість мовленнєвої компетенції як передумови опанування грамоти, а саме: бідність активного і пасивного словникового запасу; невміння будувати речення за сюжетним малюнком, за серією малюнків; встановлювати причиннонаслідкові зв'язки у процесі виконання завдань. Також зустрічалися труднощі у використанні діалогічного та монологічного мовлення, не розуміння запитань експериментатора i невміння давати правильні відповіді на них, орієнтуючись на малюнок; диференціювати стверджувальні та питальні речення; дотримуватися ритму, темпу вірша, передавати інтонацію героїв казки, сприймати прослуханий текст. 
Оскільки 3 недоліками сформованості мовленнєвої компетенції пов'язані труднощі підготовки до опанування грамоти, значна увага у підготовчий період повинна приділятися використанню перспективновипереджувального навчання, спрямованого на розвиток мовленнєвої компетенції у дітей з інтелектуальними порушеннями.

Необхідно використовувати пропедевтичні періоди, спрямовані на розвиток мовленнєвої діяльності. Корекційна робота повинна бути спрямована на збагачення словника, тобто засвоєння нових слів; уточнення словника, словниково-стилістичну роботу, оволодіння точністю і виразністю мовлення; активізацію словника, перенесення якомога більшої кількості слів із пасивного в активний словник, включення слів у речення, фрази.

Важливою умовою для розвитку мовлення дітей з інтелектуальними порушеннями є використання з першого року навчання у спеціальному дошкільному навчальному закладі спеціальних занять із розвитку мовлення, щоб вводити мовленнєвий матеріал у вільне спілкування під час прогулянок, у процесі ігор, під час ознайомлення із навколишнім середовищем, у процесі трудової діяльності, під час святкувань i розваг, під час немовленнєвих спеціальних занять із формування елементарних математичних уявлень, малювання, ліплення, конструювання, фізичного виховання, музичних занять тощо. Тобто, щоб дитина безпосередньо, сприймаючи матеріал, могла використовувати ці слова у своєму мовленні, артикулювати звуки мовлення, модулювати елементи інтонації; використовувати уміння співвідносити комплекси звуків i інтонацій із немовленнєвою реальністю, розуміти їх як смислові елементи мовлення; уміння співвідносити мисленнєві елементи мовлення зі своїми почуттями, тобто оцінювати їх; уміння запам'ятовувати традиції сполучення мисленнєвих і оціночних елементів мовлення у процесі спілкування, пізнання, мовленнєвої регуляції.

Для ефективного розвитку мовлення доцільно використовувати такі методи, як: спостереження, імітація, бесіда, переказ, розповідь, показ картин, що мало знайомі дітям за змістом, показ кінофільмів i діафільмів. До кожного запропонованого методу були підібрані різноманітні прийоми роботи.

Враховуючи особливості мовленнєвої та пізнавальної діяльності дітей 3 інтелектуальними порушеннями, необхідно поетапно, систематично ускладнювати словникову роботу в таких напрямах: оволодіння словниковим запасом у єдності зі сприйняттям предметів $\mathrm{i}$ явищ загалом; збільшення словникового запасу за рахунок розуміння слів, які позначають якості, властивості, деталі предметів і явищ, їх відношення; введення у лексичний запас слів, що позначають елементарні поняття. 
Метою і змістом основного етапу формувального експерименту було визначення найбільш ефективних шляхів навчання з підготовки до опанування грамоти дітей з інтелектуальними порушеннями старшого дошкільного та молодшого шкільного віку.

Методика корекційної роботи на основному етапі була спрямована на розвиток початкової елементарної навички читання та письма у дітей цієї категорії, зокрема: розвиток фонематичного слуху та слухового сприймання, що сприятиме формуванню уміння орієнтуватися у звуковій структурі слова; усвідомлення складової будови слова; вміння практично використовувати графічну схему слів $\mathrm{i}$ речень; розвиток зорового і просторового орієнтування; розвиток дрібної моторики рук; уміння штрихувати предмети різними лініями, виконувати завдання за зразком та інструкцією експериментатора.

Засобами реалізації виступили такі прийоми роботи: різноманітні ігри та вправи, які передбачали поетапність виконання певних дій, що забезпечують перехід від одного виду вправ до іншого. Найбільш ефективними прийомами роботи є: показ вчителем-дефектологом зразка вимовляння слова, звуконаслідування, проговорювання, коментування тощо.

У перевірці ефективності експериментальної методики брали участь 43 дитини з інтелектуальними порушеннями старшого дошкільного та молодшого шкільного віку (контрольна група (КГ) - 21 дитина, експериментальна група (ЕГ) - 22 дитини).

Результати дослідного навчання визначалися шляхом проведення однакових для дослідної та контрольної груп фронтальних письмових і усних робіт, а також індивідуальних бесід за тією самою методикою, що використовувалася на констатувальному етапі дослідження.

У табл. 1 показана динаміка результатів виконання завдань дітьми 3 інтелектуальними порушеннями експериментальної i контрольної груп ${ }^{18}$.

Таблиця 1

\section{Порівняльні дані рівнів підготовленості дітей з інтелектуальними порушеннями до опанування грамоти експериментальної} і контрольної груп (у\%)

\begin{tabular}{|c|c|c|c|c|}
\hline Групи Рівні & Високий & Достатній & Середній & Початковий \\
\hline ЕГ & 4,7 & 36,4 & 36,4 & 22,7 \\
\hline КГ & 0 & 14,3 & 47,6 & 38,1 \\
\hline
\end{tabular}

18 Кузьмінська Є.О. Підготовка розумово відсталих дітей до опанування грамоти : дис. ... канд. пед. наук. Київ, 2015. 197 с. 
Результати експериментальної роботи, отримані після формувального експерименту, свідчать, що рівень знань дітей 3 інтелектуальними порушеннями старшого дошкільного та молодшого шкільного віку, необхідних для підготовки до опанування грамоти, в експериментальній групі вищий, ніж у контрольній, оскільки на всіх рівнях виконання завдань діти експериментальної групи показали значно кращі результати. Так, до високого рівня було віднесено 4,5\% дітей експериментальної групи, а у контрольній таких дітей не було виявлено. Кількість дітей експериментальної групи, які увійшли до достатнього рівня, становила $36,4 \%$, а у контрольній $-14,3 \%$. Відповідно, до середнього рівня $-36,4 \%$ i $47,6 \%$, а на початковому рівні виконали завдання $22,7 \%$ дітей експериментальної групи і $38,1 \%$ - контрольної.

У дітей експериментальної групи на достатньому для їх навчальних можливостей рівні сформувалася мовленнєва компетенція, що стала надалі надійною основою для опанування грамоти дітьми 3 інтелектуальними порушеннями старшого дошкільного та молодшого шкільного віку. У переважної більшості дітей спостерігалося збільшення словникового запасу, значно менше виникало помилок в узгодженні слів у реченні, у процесі побудови речень частіше використовувалися прийменники, вони вміли інтонаційно правильно переказувати зміст почутого. Систематичне тренування на заняттях, у процесі використання різноманітних методів, прийомів роботи зумовило покращення рівня сформованості елементарних навичок читання та письма у дітей цієї категорії.

Таким чином, розроблена методика корекційної роботи виявилася достатньо продуктивною у підготовці дітей 3 інтелектуальними порушеннями старшого дошкільного та молодшого шкільного віку до опанування грамоти.

Виявлення підвищення якості й оперативності знань дітей експериментальної групи пояснюється доступністю i достатньою ефективністю розробленої методики корекційної роботи з підготовки до опанування грамоти дітей 3 інтелектуальними порушеннями старшого дошкільного та молодшого шкільного віку. Аналіз даних, отриманих у ході експерименту, дозволив розкрити загальну тенденцію iii впливу на протікання й результативність навчально-пізнавальної діяльності дітей зазначеної категорії.

\section{ВИСНОВКИ}

Визначені теоретичні засади підготовки дітей з інтелектуальними порушеннями старшого дошкільного та молодшого шкільного віку до опанування грамоти та проведене експериментальне дослідження дали змогу сформулювати такі висновки: 
1. Аналіз загальної та спеціальної психолого-педагогічної літератури, сучасний підхід до виховання та навчання дітей у спеціальних і загальноосвітніх дошкільних і шкільних навчальних закладах дозволяє вивчити пріоритетні напрями підготовки навчання грамоти дітей, їх мовленнєвого розвитку та формування мовленнєвої компетенції. Встановлено, що підготовка до опанування грамоти передбачає сформованість мовленнєвої компетенції та елементарних навичок читання і письма.

2. Визначені критерії та основні компоненти підготовленості дітей 3 інтелектуальними порушеннями старшого дошкільного та молодшого шкільного віку до опанування грамоти (мовленнєву компетенцію, сформованість початкової елементарної навички читання, початкової елементарної навички письма).

3. Проведене констатувальне дослідження підтвердило відомі дані про те, що на час вступу до спеціальної загальноосвітньої школи діти мають різну підготовку до опанування грамоти. Встановлена стійка залежність підготовленості до опанування грамоти від сформованості мовленнєвої компетенції у дітей 3 інтелектуальними порушеннями старшого дошкільного та молодшого шкільного віку. Враховуючи це, діти були розподілені за чотирма рівнями. Так, жодна дитина не була віднесена до високого рівня, до достатнього рівня було віднесено $14,1 \%$ дітей, до середнього - 48,4\%, до початкового $37,5 \%$.

4. Розроблено методику корекційної роботи 3 підготовки до опанування грамоти дітей з інтелектуальними порушеннями старшого дошкільного та молодшого шкільного віку, яка проходила у два етапи: підготовчий та основний.

5. Підсумковий порівняльний аналіз рівнів підготовленості дітей 3 інтелектуальними порушеннями старшого дошкільного та молодшого шкільного віку до опанування грамоти засвідчив позитивні результати під впливом корекційно-педагогічного навчання дітей в експериментальній групі. Отже, впроваджена методика корекційної роботи 3 підготовки до опанування грамоти дітей зазначеної категорії $\epsilon$ ефективною і заслуговує на подальше впровадження у педагогічну практику.

Дослідження не вичерпує усіх аспектів проблеми, що розглядається. Подальшого вивчення вимагає наступність у роботі спеціальних дошкільних і шкільних закладів освіти в аспекті забезпечення підготовки дітей з інтелектуальними порушеннями до опанування грамоти.

\section{АНОТАЦІЯ}

Дослідження присвячене актуальній психолого-педагогічній проблемі підготовки до опанування грамоти дітей з інтелектуальними порушеннями старшого дошкільного та молодшого шкільного віку. 
Розроблені в дослідженні критерії та рівні підготовленості дітей 3 інтелектуальними порушеннями до опанування грамоти i стану сформованості у них мовленнєвої компетенції дозволили виявити особливості процесу їх формування, 3 урахуванням яких розроблено методику корекційної роботи з підготовки до опанування грамоти дітей зазначеної категорії, спрямовану на розвиток мовленнєвих та основних компонентів підготовки до опанування грамоти, а також встановлення залежності їх рівня від сформованості мовленнєвої компетенції. Розроблено психолого-педагогічні та методичні заходи формування мовленнєвої компетенції дітей 3 інтелектуальними порушеннями старшого дошкільного та молодшого шкільного віку як чинника їх мовленнєвого та мисленнєвого розвитку, їхнього особистісного становлення, оптимізації міжособистісних стосунків та успішної соціалізації в суспільстві.

\section{ЛІТЕРАТУРА}

1. Базовий компонент дошкільної освіти / наук. кер. : А.М. Богуш. Київ, 2012. 26 с.

2. Богуш А.М. Витоки мовленнєвого розвитку дітей дошкільного віку: програма та методичні рекомендації. Київ : ІЗМН, 1997. 112 с.

3. Вавіна Л.С. Методичні рекомендації з вивчення грамоти учнів I-II відділень допоміжної школи. Київ : РУМК спец. шкіл, 1990. 112 с.

4. Варенцова Н.С. Возрастные особенности усвоения грамоты детьми 5-ти лет : автореф. дис. ... канд. пед. наук. Москва, 1978. 24 с.

5. Вашуленко М.С. Навчання грамоти в першому класі чотирирічної початкової школи : посібник. Київ : Рад. шк., 1986. 166 с.

6. Воронкова В.В. Обучение грамоте и правописанию в 1-4 классах вспомогательной школы : пособие. Москва : Просвещение, 1988. 100 с.

7. Воскресенская А.И. Грамота в детском саду (краткое методическое указание). Москва : Просвещение, 1965. 74 с.

8. Гнездилов М.Ф. Обучение грамоте во вспомогательной школе. Москва : Учпедгиз, 1989. 96 с.

9. Кузьмінська Є.О. Підготовка розумово відсталих дітей до опанування грамоти : дис. ... канд. пед. наук. Київ, 2015. 197 с.

10. Лурия А.Р. Высшие корковые функции человека и их нарушение при локальных поражениях мозга. Москва : Изд-во Московского ин-та, 1975. 374 с.

11. Петрова В.Г. Развитие речи учащихся вспомогательной школы. Москва : Педагогика, 1977. 200 с.

12. Програма розвитку дітей дошкільного віку 3 розумовою відсталістю. Розвиток мовлення / I.М. Дуброва, В.П. Лощених, Л.П. Шмалько. Київ, 2013. 14 с. 
13. Рєдозубов С.П. Обучение грамоте. Москва : Учпедгиз, 1952. 52 с.

14. Рождественський Н.С., Кустарева В.А. Методика начального обучения руському язику. Москва : Просвещение, 1965. 346 с.

15. Синьов В.М. Корекційна психопедагогіка. Олігофренопедагогіка: підручник. Ч. 1. Загальні основи корекційної психопедагогіки (олігофренопедагогіка). Київ : Вид-во НПУ імені М.П. Драгоманова, 2007. 238 с.

Information about the authors: Kuzminska Ye. O., Candidate of Pedagogical Sciences, Associate Professor at the Department of Psycho-Correctional Pedagogy of the Faculty of Special and Inclusive Education

National Pedagogical Dragomanov University 8/14, Turgenevskaya str., Kiev, Ukraine

Piontkivska G. S., Candidate of Pedagogical Sciences, Associate Professor, Head of the Department of Psycho-Correctional Pedagogy of the Faculty of Special and Inclusive Education

National Pedagogical Dragomanov University 8/14, Turgenevskaya str., Kiev, Ukraine 